\title{
Dendrimeric Structures in the Synthesis of Fine Chemicals
}

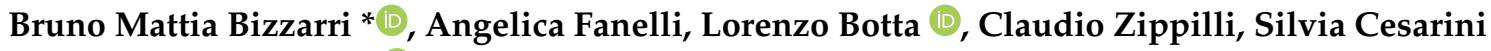 \\ and Raffaele Saladino *(i)
}

\author{
Biological and Ecological Sciences Department (DEB), University of Tuscia, 01100 Viterbo, Italy; \\ fanelli.angelica@gmail.com (A.F.); lorenzo.botta@unitus.it (L.B.); zippillic@unitus.it (C.Z.); \\ c.cesarinisilvia@gmail.com (S.C.) \\ * Correspondence: bm.bizzarri@unitus.it (B.M.B.); saladino@unitus.it (R.S.)
}

Citation: Bizzarri, B.M.; Fanelli, A.; Botta, L.; Zippilli, C.; Cesarini, S.; Saladino, R. Dendrimeric Structures in the Synthesis of Fine Chemicals. Materials 2021, 14, 5318. https://doi. org /10.3390/ma14185318

Academic Editor: Ivo Grabchev

Received: 21 July 2021

Accepted: 9 September 2021

Published: 15 September 2021

Publisher's Note: MDPI stays neutral with regard to jurisdictional claims in published maps and institutional affiliations.

Copyright: (c) 2021 by the authors. Licensee MDPI, Basel, Switzerland. This article is an open access article distributed under the terms and conditions of the Creative Commons Attribution (CC BY) license (https:/ / creativecommons.org/licenses/by/ $4.0 /)$.

\begin{abstract}
Dendrimers are highly branched structures with a defined shape, dimension, and molecular weight. They consist of three major components: the central core, branches, and terminal groups. In recent years, dendrimers have received great attention in medicinal chemistry, diagnostic field, science of materials, electrochemistry, and catalysis. In addition, they are largely applied for the functionalization of biocompatible semiconductors, in gene transfection processes, as well as in the preparation of nano-devices, including heterogeneous catalysts. Here, we describe recent advances in the design and application of dendrimers in catalytic organic and inorganic processes, sustainable and low environmental impact, photosensitive materials, nano-delivery systems, and antiviral agents' dendrimers.
\end{abstract}

Keywords: dendrimers; heterogenous catalysis; materials; PAMAM; nano-devices; anti-virals

\section{Introduction}

Dendrimers are symmetric and monodisperse macromolecules with a well-defined threedimensional branched shape inspired by that of a tree [1]. They show three topologically different regions including: (i) the core part; (ii) the branches formed by repetitive monomeric units (dendrons); and (iii) the "periphery" as final appendages of the dendrons [2]. Two different synthetic methodologies are commonly used for the preparation of dendrimers: (a) the divergent approach, in which dendrimers grow from the core proceeding radially outward toward the periphery; (b) the convergent one, in which the growth starts from the periphery of the dendrimer toward the inner part. The choice of the specific synthetic approach is usually related to the desired application field, depending on both the target chemical structure (sequence of dendrons and order of generation) and the building blocks selected for the construction of the dendritic framework. Dendrimers are classified according to the 'generation' level, which represents the minimum number of branching nodes from the core to the periphery. These systems are highly ordered three-dimensional structures often characterized by internal cavities in which metal ions and small molecules can be hosted $[3,4]$.

\section{Application of Dendrimers in the Science of Materials Field}

Dendrimers represent a potent tool in the design of novel sustainable and low environmental impact materials, as optimal reagents, or, alternatively, as structural components in the preparation and functionalization of advanced fibers and composites. For example, they can solve pollution problems associated with the dyeing of cellulose fibers, usually performed with high amounts of electrolyte and alkali solutions [5]. The application of poly-amidoamine (PAMAM) dendrimers modifies the surface of cotton fibers, increasing the dye uptake and fixation without the use of toxic substances [6]. The PAMAM treatment introduces nucleophile amino groups in the polysaccharide able to capture dyes without the use of electrolytes and alkali, minimizing the dye hydrolysis, and reducing 
the formation of wastes. Dendrimers have also been applied in the design of functional fibers that are active in the removal of organic wastes and bacteria [7]. In this context, PET-1/PAMAM $\left(\mathrm{NH}_{2}\right)$ 4-polyester nonwovens [8] showed high catalytic efficacy in the reduction of 4-nitrophenol (4-NP) into 4-aminophenol (4-AP) [9]. In this latter case, the PAMAM terminal amino groups enhanced the adsorption of 4-NP by electrostatic interactions. In addition, the system was applied for the degradation of a large panel of synthetic dyes, including Malachite Green (MG), Methylene Blue (MB), and Reactive Red 195 (RR), using $\mathrm{NaBH} 4$ as reducing agent. As an improvement, a three-layer supramolecular system based on the sandwich between PET-1/Dr and polyester nonwovens functionalized with 3(aminopropyl)trethoxysilane (APTES) and copper and silver atoms have been successfully applied as anti-bacterial materials. The functionalization of dendrimers with chromophore groups offers the possibility to create photosensitive materials to be used in catalysis, sensing, and biomedicine $[10,11]$. For example, photochromic dendrimers synthetized through Michael addition reaction between poly(amidoamine) dendrimers with three different generations (G1, G3, and G5) and azo-benzene acrylate (Azo), denoted as Gn-Azo ( $\mathrm{n}=1,3$ and 5), have been applied in the preparation of photo-switchable adhesives and healable coatings (Scheme 1) [12].
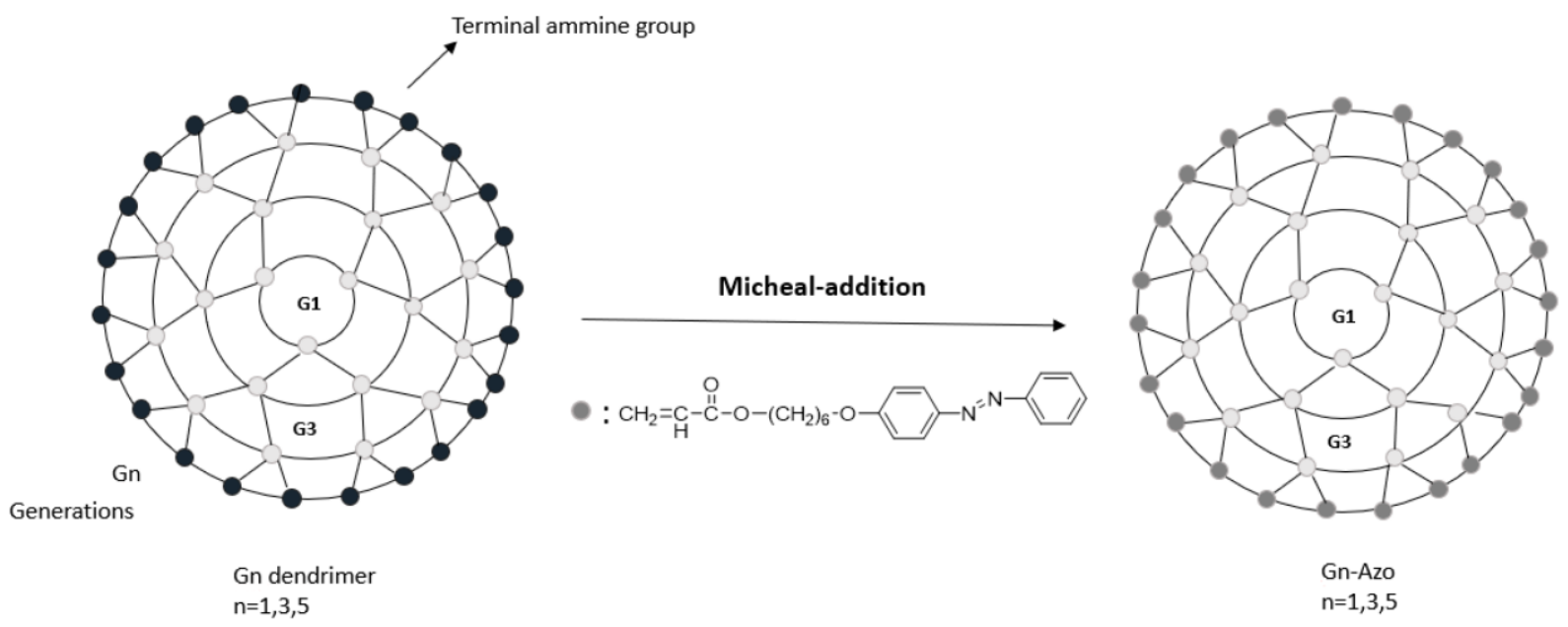

Scheme 1. Schematic representation of the synthesis of photochromic dendrimers.

In this system, the azo-benzene group is subject to photo-isomerization phenomena (trans versus cis isomer) associated to the $\mathrm{n}-\pi^{*}$ transition after UV irradiation. Conversely, visible light irradiation reverted the isomerization to trans form $[13,14]$. This effect influences the glass transition temperature of dendrimers [15], making them available for reversible adhesive capability when irradiated with visible or UV light. Interestingly, this property was found to increase by raising the dendrimer generation. For example, the adhesion strength of the fifth-generation dendrimers (G5-Azo) can reach up to $1.62 \mathrm{MPa}$, which is five times higher than that of pristine azo-benzenes. Finally, the use of dendrimers in the production of controlled porous silica materials for catalysis, bio-separation, and biomedicine applications, has been reported and discussed [16]. In this context, PAMAM characterized by a tetra-functional ethylene-diamine core acts as an organic template for the preparation of mesoporous silica materials [17]. PAMAM generation zero to three bearing amine terminal group and PAMAM generation two bearing alkylated quaternary ammonium terminal groups produced mesoporous silica materials with high mono-dispersion of the pre diameter (3-9 nm). In addition, due to the hydrogen bond affinity between water and amino group at the periphery of the PAMAM, the template was easily removed from the silica by a simple extraction procedure, without the use of polluting organic solvents. PAMAM recycling tests showed that the dendrimer is rarely wasted and maintains good chemical stability, furnishing well-defined mesoporous silica material with large surface area, pore volume, controllable pore diameter, and narrow pore size distribution. 


\section{Nano-Delivery Systems}

The well-defined three-dimensional structure of dendrimers make them a suitable class of macromolecular nano-scale delivery devices [18] with promising solubility and targeted delivery properties [19]. Dendrimer nano-devices conjugated with gallic acid have been reported as a novel drug-delivery strategy for the therapy of chemo-resistance in neuroblastoma cells [20]. Human neuroblastoma (NB) is a pediatric tumor that usually develops resistance to therapy due to the overproduction of reactive radical oxygen species (ROS). In this regard, gallic acid can prevent cancer due to the presence of the phenolic pharmacophore [21,22]. The bioavailability of gallic acid is low due to its low solubility in both water and alcohols [23]. Biodegradable dendrimer based on a fifth-generation polyester (G5) inner matrix with tree-like repetition of 2,2-bis (hydroxymethyl)propionic acid and 64 peripheral hydroxyl groups, namely matrix 4 (Figure 1), has been applied as a gallic acid-enriched nano-device for the treatment of chemo-resistant neuroblastoma cells [24].<smiles>O=C(O[Si](OC(=O)C(CO)CO)(OC(=O)C(CO)CO)OC(=O)C(CO)CO)O[Si](OC(=O)C(CO)CO)(OC(=O)C(CO)CO)OC(=O)C(CO)CO</smiles>

Figure 1. Biodegradable dendrimer matrix 4.

Gallic acid, a polyphenol largely used beside its derivatives as a potent antioxidant [25-27], was supported by a covalent bond with the dendrimer backbone, or, alternatively, by encapsulation and surface absorption on the polymer matrix 4 (Figure 2).<smiles>O=C(OCC(COC(=O)C(COC(=O)c1cc(O)c(O)c(O)c1)COC(=O)C(COC(=O)c1cc(O)c(O)c(O)c1)OOC(=O)C(COC(=O)c1cc(O)c(O)c(O)c1)COC(=O)c1cc(O)c(O)c(O)c1)C(=O)OCOc1cc(O)c(O)c(O)c1)c1cc(O)c(O)c(O)c1</smiles>

Figure 2. Gallic acid, supported on the polymer matrix 4 (grey core).

Functionalized dendrimers exhibited a ROS-mediated cytotoxic activity on chemoresistant cancer cells at a concentration of almost 100 times lower than that of gallic acid alone. The conjugation strategy, involving dendrimers and bioactive substances, was also effective in the case of PAMAM dendrimer-azithromycin conjugate nano-devices active against chlamydia trachomatis infections [28]. Chlamydia trachomatis is an obligate intracellular bacterium responsible for sexually transmitted infections that are resistant to antibiotic therapy $[29,30]$. Azithromycin (AZ)-conjugated 4-generation (G4) of PAMAM dendrimers bearing $\mathrm{OH}$ group in the terminal position (PAMAM G4-OH-AZ) have been 
synthesized in order to use the hydroxyl-end-functionality as "ester-link" for the controlled release of the drug (Scheme 2).

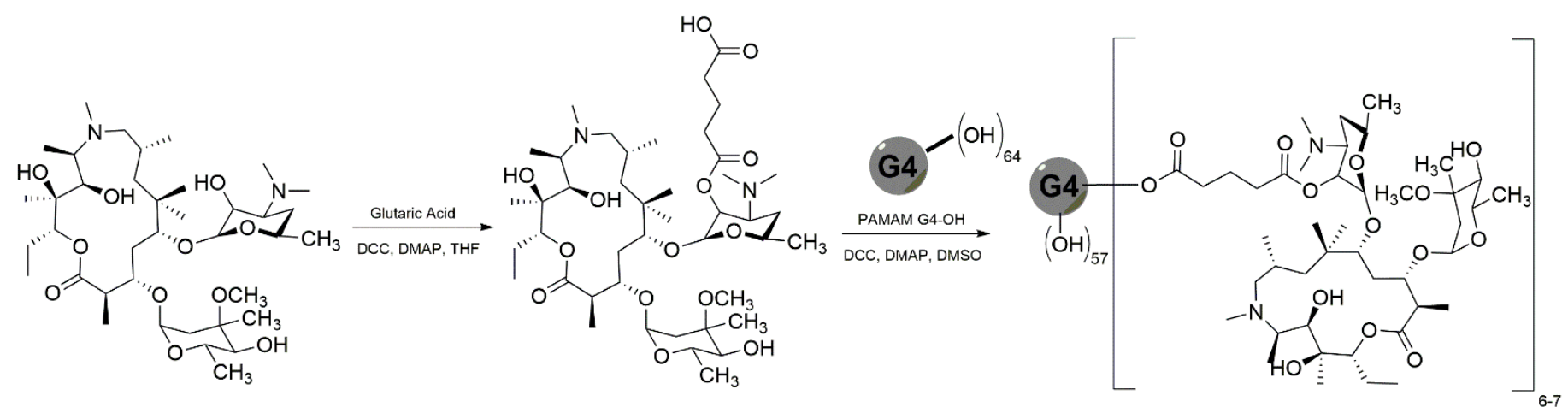

Scheme 2. Synthesis of Azithromycin conjugated with G4 PAMAM dendrimers.

Azithromycin was first reacted with glutaric acid using DCC, DMAP, and trimethylamine, followed by esterification with PAMAM G4-OH. Kinetic studies of the release of $\mathrm{AZ}$ confirmed the efficacy of the nano-device which was more effective than AZ alone in the treatment of Chlamydia Trachomatis. A further study described the use of a third generation (G3) of PAMAM dendrimers as nano-carriers of paclitaxel, a known anticancer agent inhibitor of P-glycoprotein and Topoisomerase 1 [31,32]. Paclitaxel is applied in the treatment of various cancers, including non-small cell carcinomas of the ovary, breast, and lung [33]. However, its therapeutic efficacy is limited due to poor solubility and permeability. To solve these biases, paclitaxel (Pac) has been covalently linked via a glutaric anhydride (glu linker) to PAMAM dendrimer bearing lauryl acid side-chains (lauryl-G3 PAMAM: G3L3, G3L6) [34]. In this way, Pac was linked to glutaric anhydride via an ester bond and to lauryl-G3 PAMAM or G3 PAMAM via an amide bond (Scheme 3) [35].

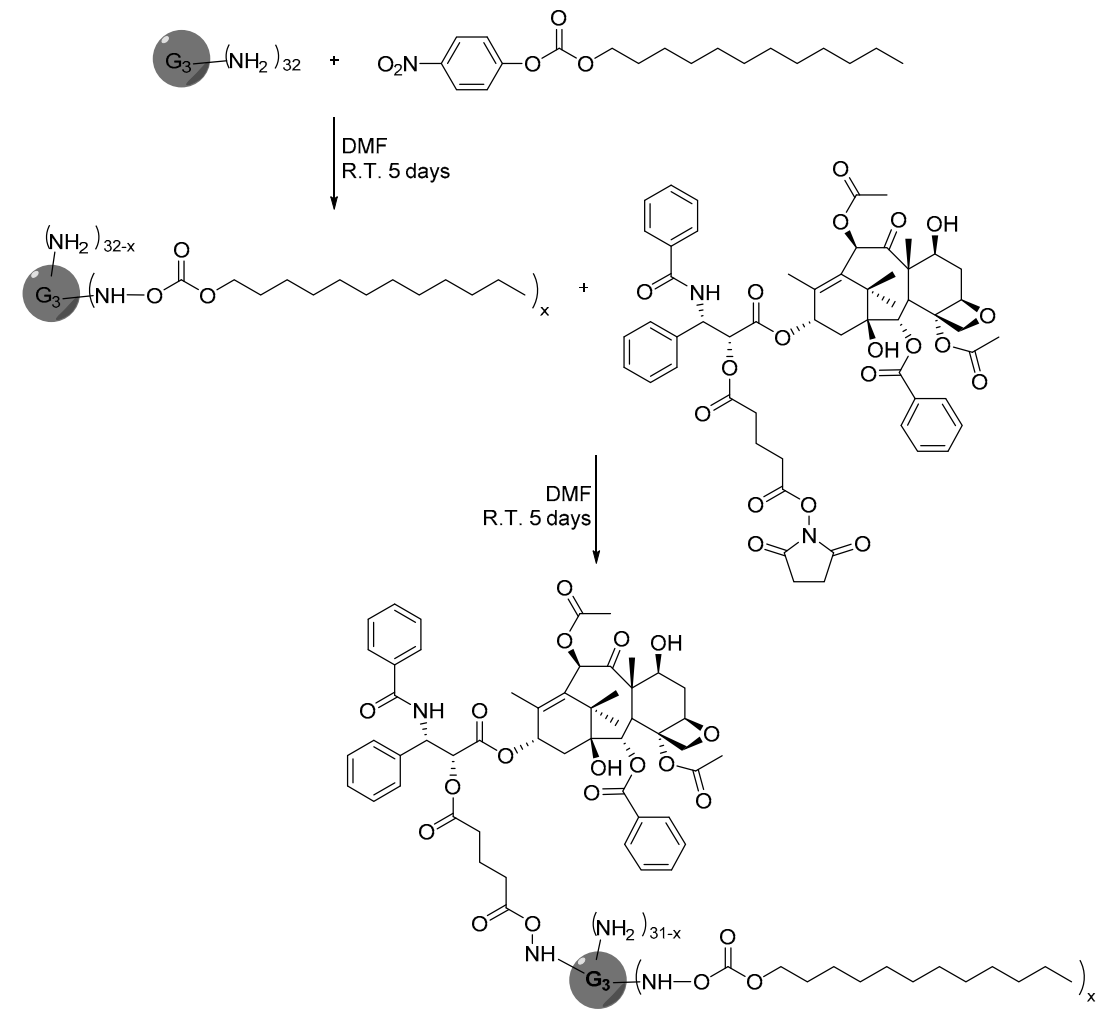

Scheme 3. Synthesis of paclitaxel/PAMAM dendrimer bearing lauryl acid side-chains. 
Modified dendrimers showed appreciable activity against human colon adenocarcinoma cell line (Caco-2) and primary cultured porcine brain endothelial cells (PBECs). The analysis showed an increased toxicity of the modified dendrimers with respect to the native counterpart. In addition, the novel nano-devices showed the highest permeability in both apical-to-basolateral and basolateral-to-apical directions across both cell monolayers, probably, due to the occurrence of a lauryl side-chain favored interaction with the plasma membrane. The surface engineering of dendrimers can further improve their application as nano-carriers. For example, the surface of G4 PAMAM dendrimers have been modified by using polyethylene glycol and folic acid [36] in order to reduce the amount of free terminal $\mathrm{NH}_{2}$ groups which are responsible for toxicity [37-39]. The application of these platforms for the selective release of anti-cancer bioactive agents, such as 5-fluorouracil (5FU), was reported focusing on the effect against human colorectal cancer (Figure 3).

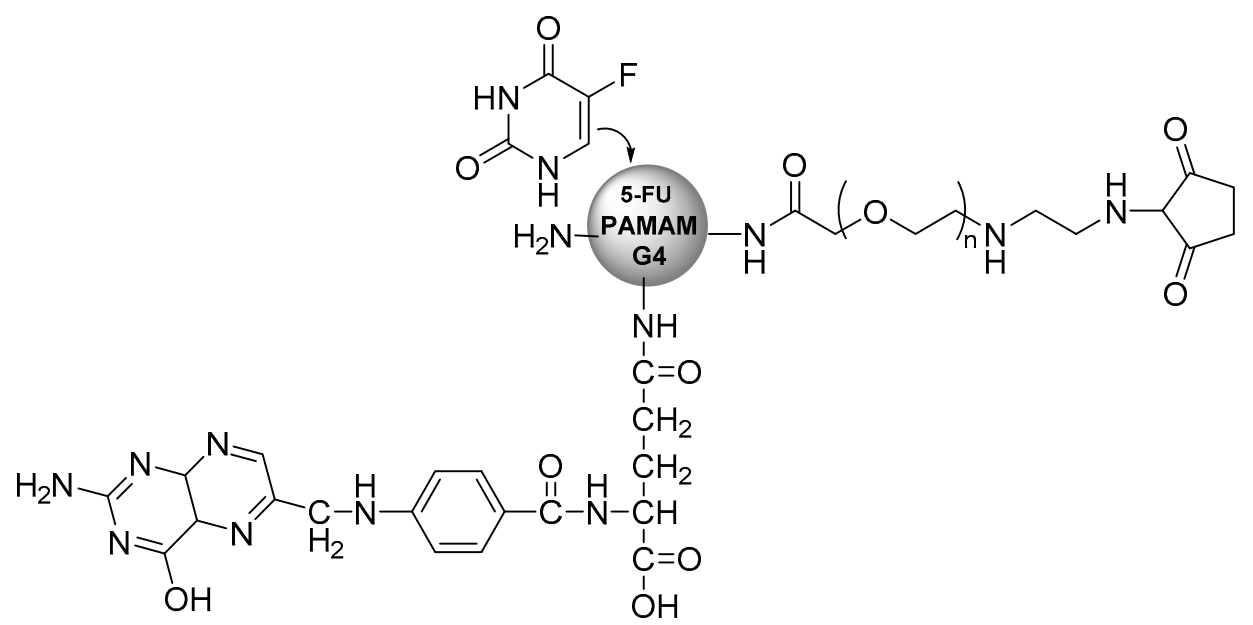

Figure 3. Structure of PAMAM G4 dendrimer platforms as a carrier of 5-fluorouracil.

Due to their biodegradability and biocompatibility profile, dendrimers have also been used in agricultural and agro-industrial fields. For example, water-soluble nano-sized cationic dendrimers containing hydrophobic and peripheral dendritic polyester amines demonstrated their capability to carry out the hydrophobic pesticide thiamethoxan [40]. In this latter case, three generations (G1, G2, and G3) of functionalized cationic dendrimerbased nano-carriers, consisting of a fluorescent perylene-3,4,9,10-tetracarboxydiimide chromophore core (PDI) and amino groups at the periphery (Figure 4), were used as a nanodevice by loading of the pesticide through formation of electrostatic interactions [41]. The drug release was significantly facilitated by the terminal amino groups that increased the water solubility of the dendrimer. All three generations of water-soluble fluorescent PDI-cored cationic dendrimers effectively delivered the drug in live cells; in particular, second and third generations of nano-carriers showed an increasing drug cytotoxicity to insect pests with respect to the drug alone. 


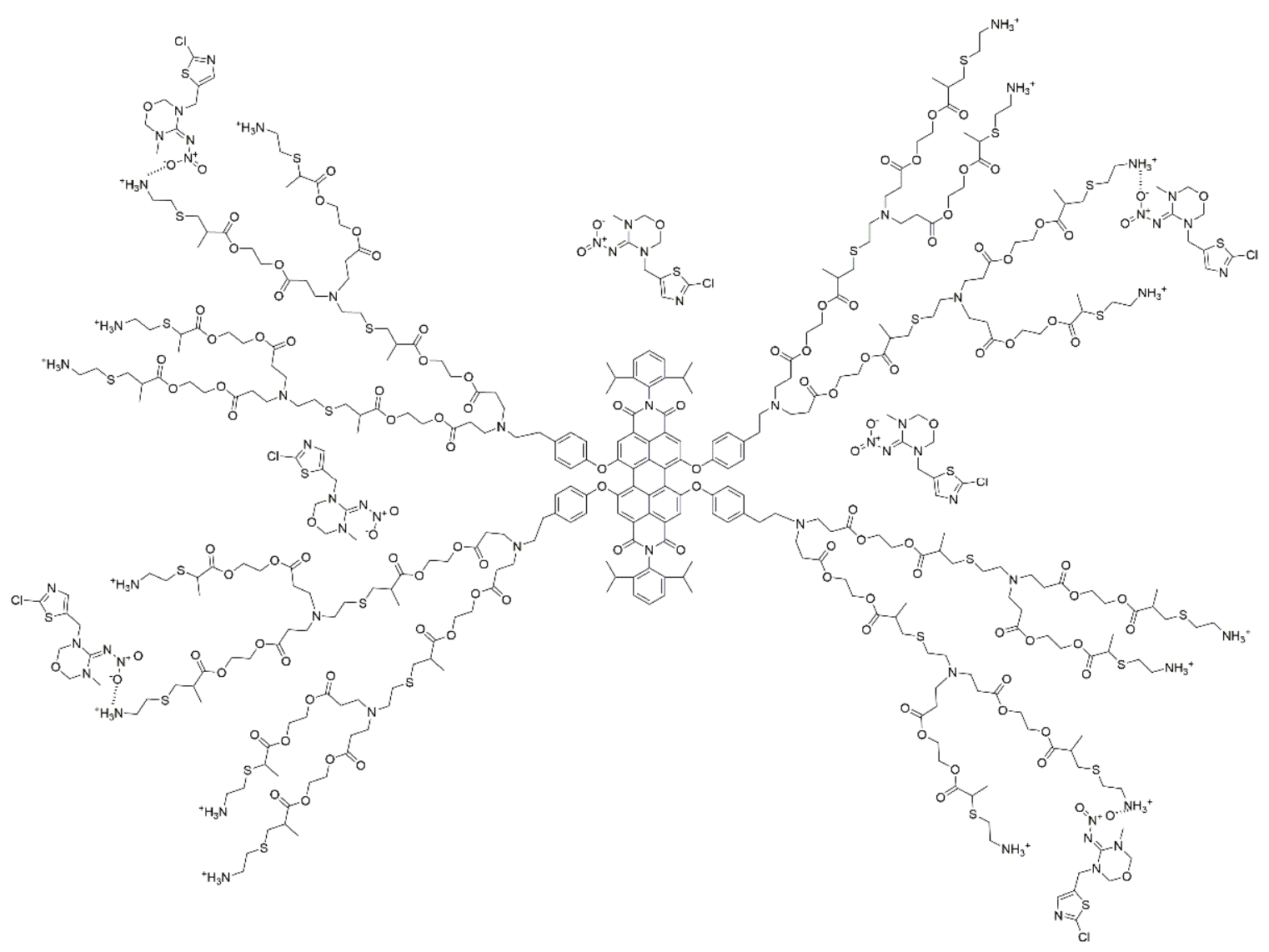

Figure 4. Structure of fluorescent perylene-3,4,9,10-tetracarboxydiimide chromophore core as a nano-device for pesticides.

\section{Application of Dendrimers in Catalysis}

Dendrimers are efficient platforms for the preparation of heterogeneous catalysts based on metal nanoparticles, such as palladium nanoparticles. Pd-based dendrimers have been reported as a green alternative for palladium-based organometallic reactions, including Still, Sonogashira, Mizorocki-Heck, and Suzuki-Miayura reactions [42-44]. Catalytic systems encompassing palladium nanoparticles immobilized on dendrimers showed simple recoverability and reusability, avoiding drawbacks related to the leaching of the metal, purification of final products, and toxicity of common metal ligands. In addition, the combination of magnetic nanoparticles and dendrimers opened a new entry for fast, simple, and inexpensive recovery procedures [45-47]. In this context, capped guanidine third-generation dendrimer supported on $\mathrm{Fe}_{3} \mathrm{O}_{4} @ \mathrm{SiO}_{2}$ nano-materials were used for the encapsulation of Pd nanoparticles (G3-Gu-Pd; Scheme 4) [48], and applied in the MizorokiHeck and copper-free Sonogoshira reactions under environmentally friendly conditions. The authors reported several examples of the Mizoroki-Heck coupling reaction between aryl halides 1 and alkenes 2 in the presence of G3-Gu-Pd catalyst $\left(\mathrm{K}_{2} \mathrm{CO}_{3}\right.$, SDS surfactant) in water at $100{ }^{\circ} \mathrm{C}$ to yield 3 in high yields (62-91\%). In addition, G3-Gu-Pd catalyst was applied in the copper-free Sonogashira reaction of aryl halides 4 with acetylene compounds 5 to afford 6 in high yields (60-90\%).

The use of silica supported phosphine-palladium terminated PAMAM dendrimers in the Heck condensation between aryl bromides and a panel of alkenes, such as styrene and butyl acrylate, was also reported (Figure 5) [49]. The catalyst was prepared by reaction of palladium complex $\left[\mathrm{Me}_{2} \mathrm{NCH}_{2}-\mathrm{CH}_{2} \mathrm{NMe}_{2}\right] \mathrm{PdMe}_{2}$ and the supported phosphine dendrimer (G0-G4), with the stability of the system being increased significantly from G0 to G4 generation of PAMAM. These catalysts were effective in the coupling between bromo-benzene and styrene to yield (E)-stilbene with appreciable selectivity, opening new synthetic perspectives preparation of bioactive stilbene derivatives [50]. 
Mizoroki-Heck<smiles>[R][R]1ccc(/C=C/c2cccc(/C=C/c3ccc([R2])cc3)c2)cc1</smiles>

$362-91 \%$
Copper-free Sonogoshira

Scheme 4. Schematic representation of G3-Gu-Pd catalyst and its application in the Mizoroki-Heck and the copper-free Sonogashira reaction of aryl halide 1 and 4 with alkene 2 and acetylene derivatives 5 , respectively.

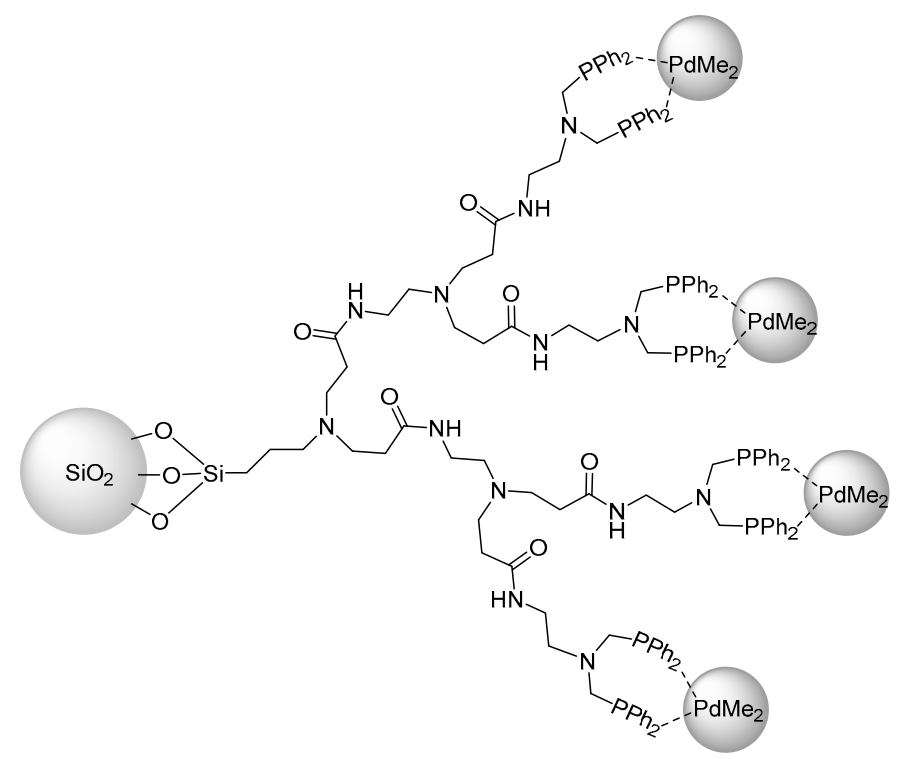

Figure 5. Schematic representation of second-generation silica supported phosphine-palladium terminated PAMAM dendrimers.

Highly efficient heterogeneous catalysts for the hydrogenation of conjugate double bonds have been prepared by combining silica-polyamine composite (SPC BP-1) with poly-propyleneimine (PPI) dendrimers containing Pd nanoparticles (Scheme 5). These catalysts were effective for the selective hydrogenation of isoprene, phenyl-acetylene, and 2,5-dimethyl-2,4-hexadiene [51-53]. The catalyst was obtained by reacting the imine derivative of SPC BP-1 with the third-generation of poly-propyleneimine (PPI) dendrimers, followed by loading with $\mathrm{Pd}(\mathrm{II})$ as $\mathrm{Pd}(\mathrm{OAc})_{2}$. The reduction of the $\mathrm{Pd}(\mathrm{II})$ precursor with sodium borohydride afforded the effective $\operatorname{Pd}(0) \mathrm{DAB}\left(\mathrm{NH}_{2}\right) 16^{*} \mathrm{Pd}^{0} @ \mathrm{BP} 1$ (Scheme 5). This hybrid showed high efficiency in the hydrogenation of dienes under hydrogen pressure of $3 \mathrm{MPa}$ and a substrate/Pd ratio of 66240 , resulting in $85 \%$ of conversion and a selectivity 
of alkene products of $98 \%$. No leaching of Pd was reported and the catalyst was effective for four cycles without loss of activity. Moreover, the catalyst showed higher activity in comparison to PPI dendrimers alone or Lindler catalyst.

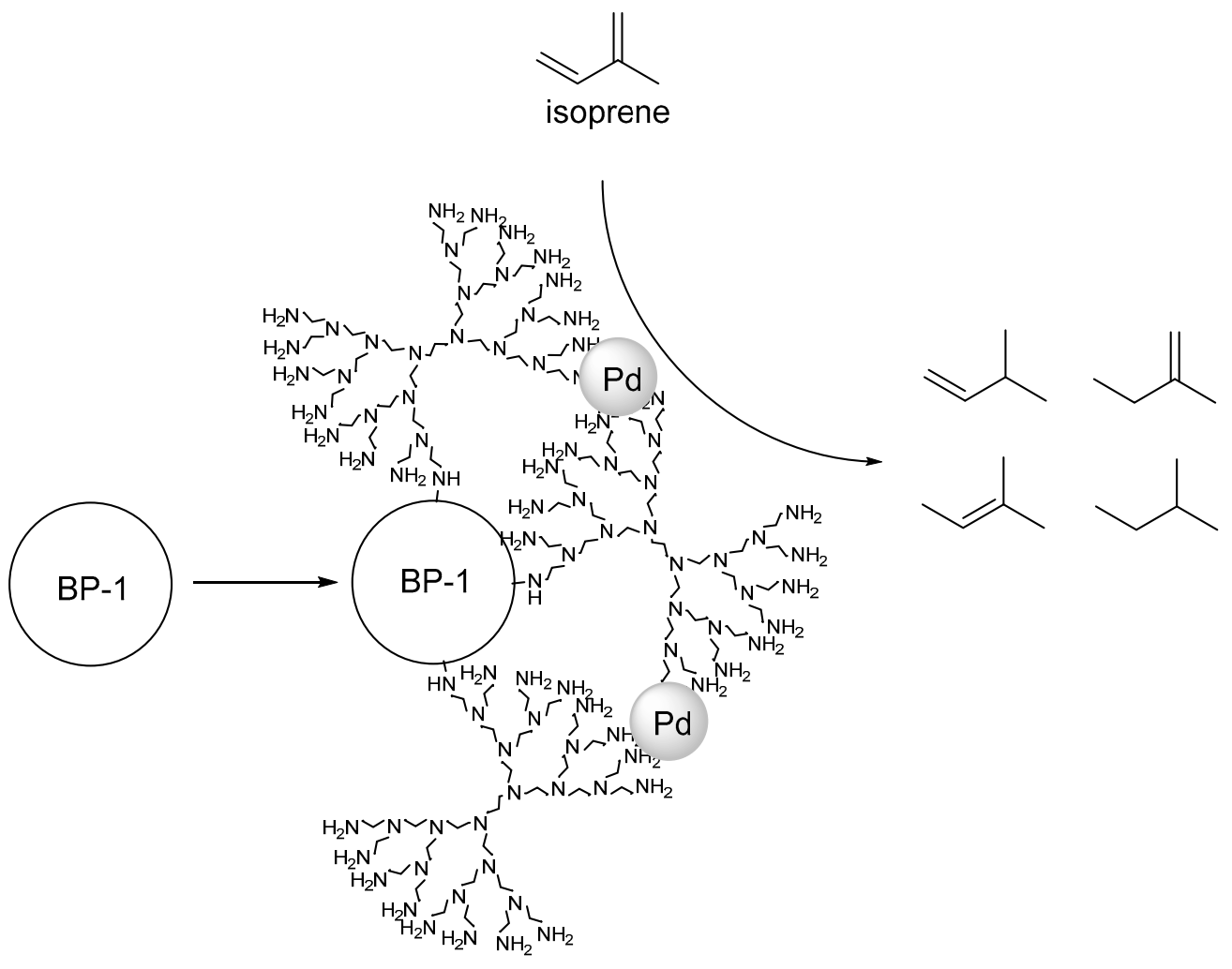

\section{$\mathrm{DAB}\left(\mathrm{NH}_{2}\right)_{16}{ }^{*} \mathrm{Pd}^{0} @ B P 1$}

Scheme 5. Application of $\mathrm{DAB}\left(\mathrm{NH}_{2}\right)_{16}{ }^{*} \mathrm{Pd}^{0} @ \mathrm{BP} 1$ catalyst in the selective hydrogenation of isoprene.

Dendritic heterogeneous catalyst based on palladium nanoparticles have also been reported to effectively catalyze C-S cross-coupling reactions. In this context, palladium nanoparticles immobilized on nano-silica triazine dendritic polymer (Pdnp-nSTDP) are effective catalysts for the synthesis of diaryl and aryl-heteroaryl sulfides under microwave (MW) irradiation $\left(230 \mathrm{~W}, 80{ }^{\circ} \mathrm{C}\right)$, in the presence of tetra-butylammonium hydroxide (TBAH) in $1 \mathrm{H}_{2} \mathrm{O}-\mathrm{DMF}$ mixture (Scheme 6) [54]. Pdnp-nSTDP were prepared starting from a nano-silica 3-amino-propyl-trimethoxysilane platform, followed by the in situ generation and entrapment of $\mathrm{Na}_{2} \mathrm{Pd}_{2} \mathrm{Cl}_{6}$. Pdnp-nSTDP were also effective in the C-S cross coupling with low reactive aryl chlorides (Scheme 6). The catalyst retained its activity for five successive runs.

The ability of dendrimers to adsorb and stabilize metal nanoparticles inspired their application in the environmental remediation of toxic metals, such as copper, lead, and chromium, in the aqueous environment. For example, poly(N-propylethane-1,2-diamine) G3 bearing a magnetite core and capped with a carboxylic acid moiety $\left(\mathrm{Fe}_{3} \mathrm{O}_{4} / \mathrm{SiO}_{2} / \mathrm{PNPEDA}\right.$ G3-COOH) showed a high efficacy in the chelation of heavy metals (Figure 6) [55]. In addition, it was easily recoverable and regenerated by a simple acid treatment. 
<smiles>Cc1ccc(SSc2ccc(C)cc2)cc1</smiles>

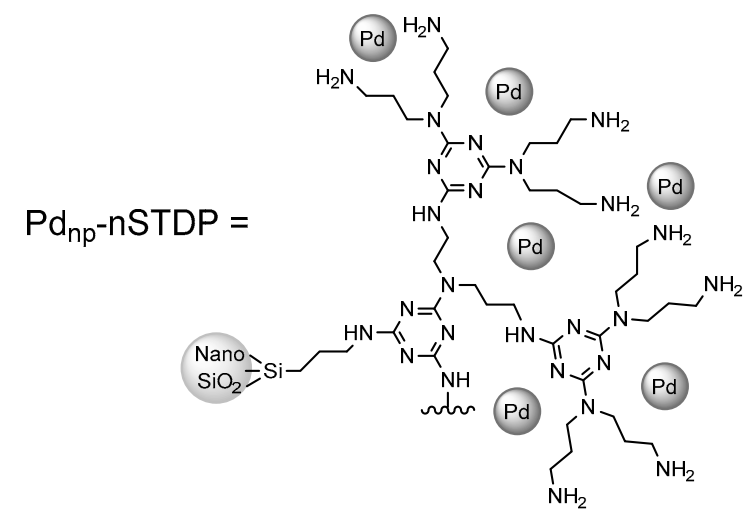

Scheme 6. Palladium nanoparticles immobilized on nSTDP dendrimers in the C-S coupling reaction.

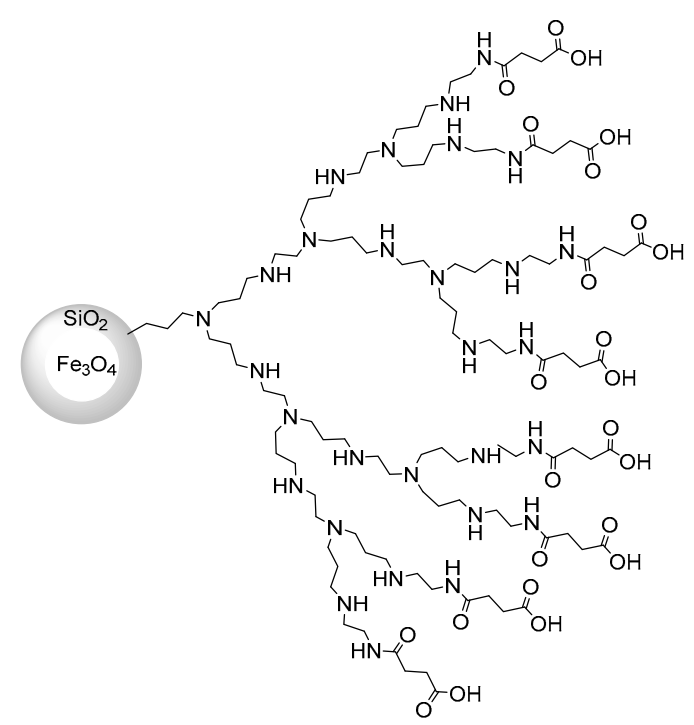

Figure 6. Schematic representation of the $\mathrm{Fe}_{3} \mathrm{O}_{4} / \mathrm{SiO}_{2} /$ PNPEDA G3-COOH nanomaterial.

\section{Dendrimers Application in Organo-Catalysis}

The application of PAMAM dendrimers in different fields of organic chemistry, including multicomponent reactions, heterocycles synthesis, and organo-catalysis, are reported and discussed [56]. Porphyrin-cored poly(amidoamine) (G1 POR-PAMAM) dendrimers act as homogeneous catalysts in the multi-component Biginelli and Hantzsch reactions [57]. G1 POR-PAMAM were synthesized by a multi-step procedure encompassing the nucleophilic ring opening of epichlorohydrin with hydroxyphenyl porphyrin, azidation, and reduction, followed by methyl acrylate tandem Michael addition and trans-amination with ethylenediamine (Figure 7). G1 POR-PAMAMs catalyzed the synthesis of 1,4-dihydropyridine and 3,4dihydropyrimidin-2(1H)-thione derivatives, starting from aldehydes, ethyl-acetoacetate, and ammonium thiocyanate, in a single step and in a short time (45 min), with almost quantitative yield (92-99\%) (Scheme 7). 


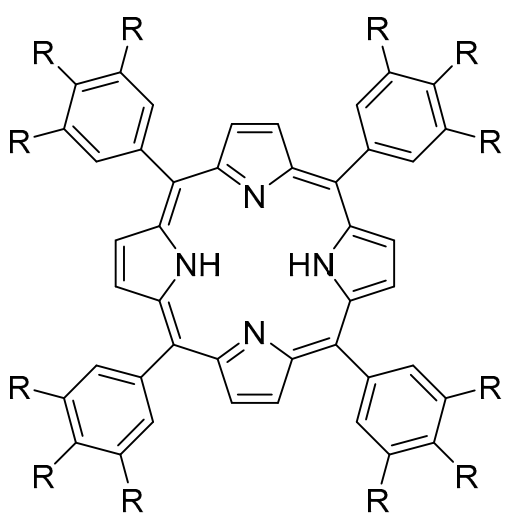<smiles>[R]CC(COC(CN(CCC(=O)NCCN)CCC(=O)NCCN)CN(CCC(=O)NCCN)CCC(=O)NCCN)OC</smiles>

Figure 7. Structure of the catalyst porphyrin cored poly(amidoamine) (G1 POR-PAMAM) dendrimers.

A similar procedure has been applied for the preparation of pentaerythritol-based dendritic nanostructures endowed of catalytic activity [58]. In this latter case, the authors applied an azide-mediated ring opening of epichlorohydrin, followed by reduction of the cyano moiety, tandem Michael addition, and trans-amination with ethylene diamine. The growing of the dendrimer was characterized by the use of MALDI-TOF/MS, then FTIR, NMR, and, when necessary, by TEM microscopy.

A)<smiles>CCOC(=O)CC(C)=O</smiles>

$\mathrm{NH}_{4} \mathrm{SCN}$

B)<smiles>CCOC(=O)CC(C)=O</smiles>

\section{G1 PAMAM}<smiles>CCOC(=O)C1=C(C)NC(=S)NC1c1ccccc1</smiles>

Scheme 7. (A) Synthesis of 1,4-dihydropyridine by Hantzsch pyridine synthesis (B) Synthesis of 3,4-dihydropyrimidin-2 $(1 \mathrm{H})$-thione derivatives by Biginelli reaction.

The catalytic activity of these PAMAMs was evaluated on the multicomponent synthesis of bis-imidaziole derivatives starting from 1,2-diketones, aromatic aldehydes, bis(3aminopropyl)amine, aromatic aldehydes, and ammonium acetate (Scheme 8). Electrondonating groups $\left(-\mathrm{OH},-\mathrm{OCH}_{3}\right)$ on the aromatic aldehyde increased the yield of the products compared to electron-withdrawing substituents $\left(-\mathrm{NO}_{2},-\mathrm{Cl}\right)$, with the catalyst retaining its activity for more runs. Some of the novel compounds showed inhibitory activity against $17 \beta$-hydroxysteroid dehydrogenase type 1 (17 $\beta$-HSD1, PDB code 3HB5), a key enzyme active in breast cancer and estrogen-related diseases. 


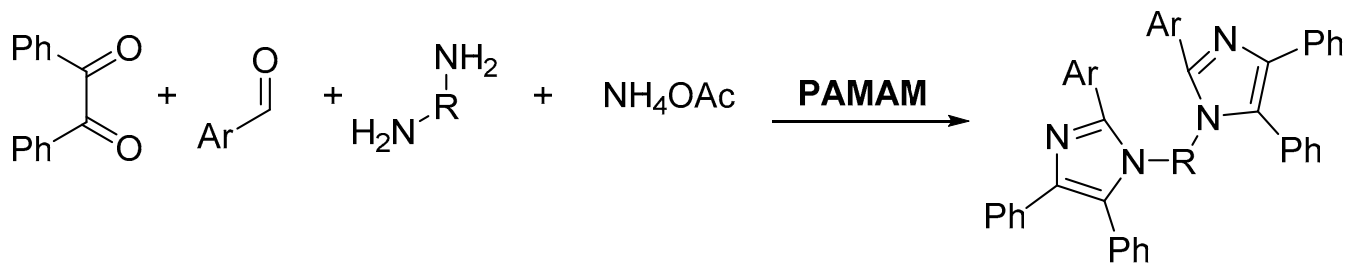

Scheme 8. Multicomponent synthesis of bis-imidaziole derivatives starting from 1,2-diketones, aromatic aldehydes, bis(3-aminopropyl)amine with aromatic aldehydes, and ammonium acetate.

Dendronized polymers in which cavity and surface functionalities are the reactive centers of unimolecular micelles self-assembled in aqueous medium have been prepared from tris(hydroxymethyl)propane, epichlorohydrin, sodium azide, and acrylonitrile (instead of methyl acrylate) [59]. These aggregates act as homogeneous organo-catalysts for the one-pot synthesis of 4-aryl-1H-1,2,3-triazoles, starting from aldehyde, nitromethane, and sodium azide (Scheme 9). It was observed that meta-substituted aldehydes afforded lower yields compared to ortho- and para- substituted aldehydes, and the formation of dendritic unimolecular micelle in aqueous solution simplified the product isolation and catalyst recycling. The product could be isolated by simple extraction with organic solvents, and the dendritic molecular micelle was recovered by simple centrifugation of the water medium. In addition, the catalyst was reused up to six cycles retaining a high activity.<smiles>[R]c1ccc(-c2c[nH]nn2)cc1</smiles>

Scheme 9. One pot synthesis of 4- aryl-1H-1,2,3-triazoles starting from aldehyde, nitromethane and sodium azide.

The role of PAMAM functionalized with chloro-sulfonic acid as Brønsted acid organocatalyst has been reported [60]. In this latter case, ethylene diamine was polymerized with methyl acrylate and chloro-sulfonic acid to generate the sulfamic acid functionalities (Scheme 10). The novel catalyst was used for the synthesis of acetals from aldehydes and acetic anhydride at room temperature and under solvent-free conditions. In addition, the catalyst was able to perform the inverse reaction of de-protection of acetals to corresponding aldehydes, showing, in both cases, a good recyclability.

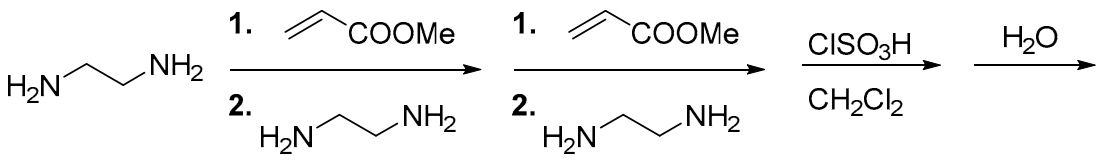<smiles>[R]NC(=O)CCNCCN(CCC(N)=O)CC(=O)N[R]</smiles>

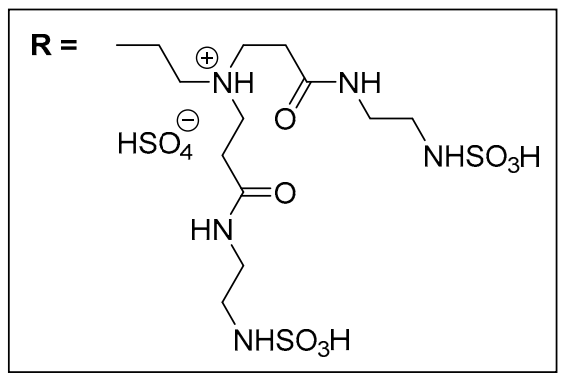

Scheme 10. Synthesis and structure of the functionalized PAMAM Dendrimer endowed with Strong Ionic Brønsted Acid properties. 
The mechanism of action was rationalized by the study of the Hammett acidity function and compared with $\mathrm{NH}_{2} \mathrm{SO}_{3} \mathrm{H}$. A strong Brønsted acid behavior was observed as a consequence of the multi-functional and high proton loading level of the dendrimer (Scheme 11).

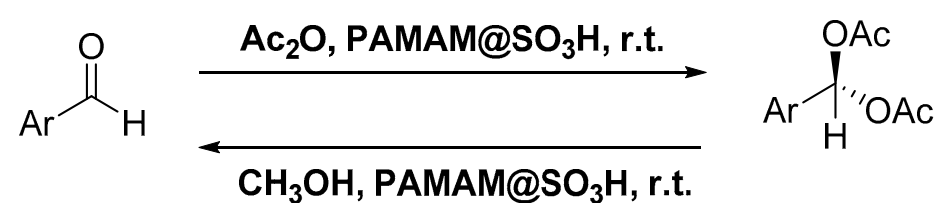

Scheme 11. Synthesis of 1,1-diacetyl from aldehydes and acetic anhydride at room temperature and under solvent-free conditions, and deprotection of the diacetyl product to afford the corresponding aldehydes.

PAMAM dendrimers can also perform as a coordinative functional platform for the immobilization of reactive heavy-metal/benzo-15-crown-5 ether complexes on multiwall carbon nanotubes (MWCNTs) [61]. Three different heterogeneous catalysts were obtained by the following procedures: (i) introduction of ethylene diamine spacer on inert MWCNTs and decoration of the amine functionalities with benzo-15-crown-5 ether to yield linear dendrimer species (Scheme 12); (ii) dendrimerization of the diamine spacer on the carbonaceous nanotube by methyl acrylate addition followed by crown ether coupling (Scheme 13).

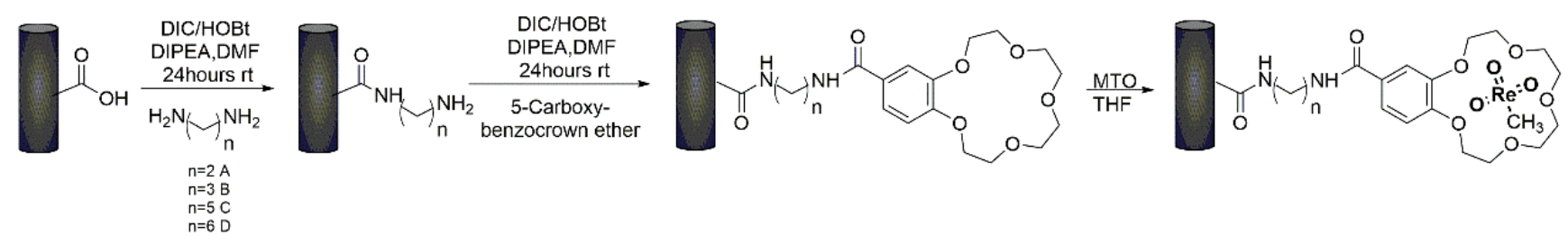

Scheme 12. Synthesis of linear polymeric catalyst.

In both cases, the catalysts were loaded with MTO that is a potent activator of hydrogen peroxide by formation of rhenium peroxide intermediates (Scheme 14). The novel branched catalysts efficiently transformed olefins into the corresponding epoxides, while the linear counterpart afforded mainly diol derivatives.



Scheme 13. Synthesis of 2nd generation PAMAM catalysts. 


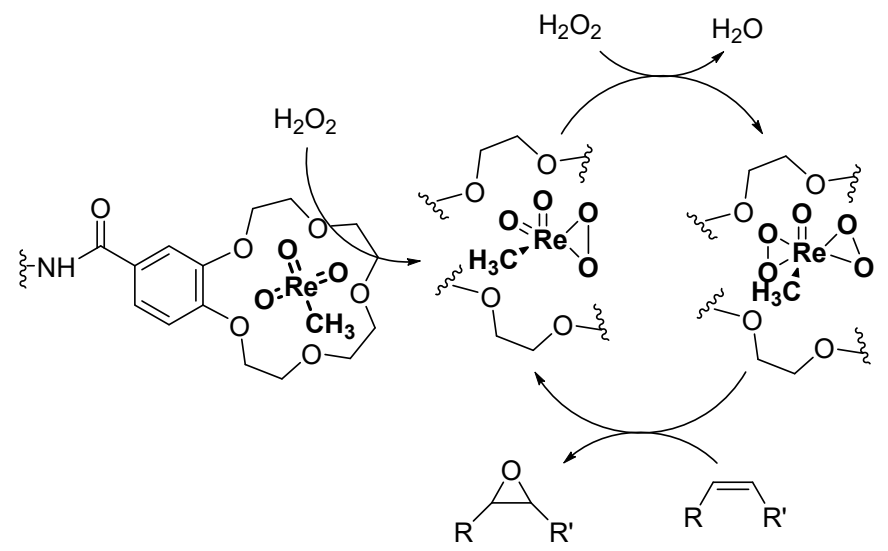

Scheme 14. Schematic representation for MTO/ $\mathrm{H}_{2} \mathrm{O}_{2}$ epoxidation of olefines.

\section{Dendrimers as Antiviral Agents}

Peptides and derivatives have shown an enormous therapeutic potential for the treatment of different viral infections, due to their high biocompatibility, selectivity for targets, low toxicity, and easy elimination [62,63]. The effectiveness of peptides in the inhibition of viral agents has been improved by the synthesis of dendrimers. The antiviral efficacy of dendrimers is usually associated to their similarity to biomimetic peptides, high stability (protease resistance), lack of conformational effects, and, when necessary, high capability to carry out drugs [64]. In this latter case, the hydrophobic drug is bonded near the hydrophobic cores, while the hydrophilic external surface favors the solubility of water. Dendrimers showed appreciable antiviral activity against influenza virus, human immunodeficiency virus, and respiratory syncytial virus.

The functional groups located at the periphery of the system can block the entry of the virus by competing with the cell, (Figure 8 ) or by exerting direct effects on viral replication [65,66]. In particular, dendrimers modified with naphthyl residues and sulfonate groups have been found to be active against Herpes Simplex virus and HIV [67]. Peptides conjugated with dendrimers exhibit several benefits with respect to corresponding peptides or dendrimers alone. Peptide dendrimers are easily synthesized, preserve their activity at low- and high-salt conditions, are resistant to the activity of proteases, and generally show a low toxicity. Sialic acid conjugated poly-amidoamine (PAMAM) dendrimers (G4-SA) have been synthesized in the frame of the prevention of influenza A H1N1, H2N2, and H3N2 infection. These compounds showed inhibitory activity against H3N2 and H1N1 influenza subtypes in hemagglutination-inhibition assays. Other types of dendrimers bearing a charged group on the surface have also been reported as inhibitors of MERS-CoV. These systems are anionic dendritic polymers, including hydroxyl, carboxyl, and succinic acid substituents, or in alternative cationic dendritic polymers containing primary amine end groups.

In particular, polymers bearing a carboxyl and a succinic acid moieties exhibited the best inhibition values, probably, due to a hydrogen and $\mathrm{p}-\mathrm{p}$ stacking interaction between the viral fusion protein and the dendrimer [68]. PAMAM dendrimers have also been conjugated with different sugar moieties as potential inhibitors of human and avian influenza virus strains. In this latter case, sialyllactose (6SL) PAMAM derivatives showed interesting activity against human and avian strains. The application of sialyllactose moiety in the PAMAM dendrimers was further analyzed in the case of PAMAM dendrimers of generation 4 and 5 bearing up to 128 sialyllactose ligands.

These compounds showed a potent antiviral activity in the low micro-molar range [69,70]. In addition, G1-G3 poly-anionic carbosilane dendrimers (Figure 9) have recently been reported as active compounds against HIV-1 [71]. When tested alone or in combination with latency-reversing agents (LRAs) bryostatin-1,2, panobinostat, and romidepsin (RMD), they significantly increased the expression of cell lines latently infected with HIV-1 p89GFP (GFP). The results showed an enhanced expression of GFP until $80 \%$, proving that a combi- 
natory treatment in the "shock and kill" method with dendrimers could also help with the reactivation activity of LRAs.

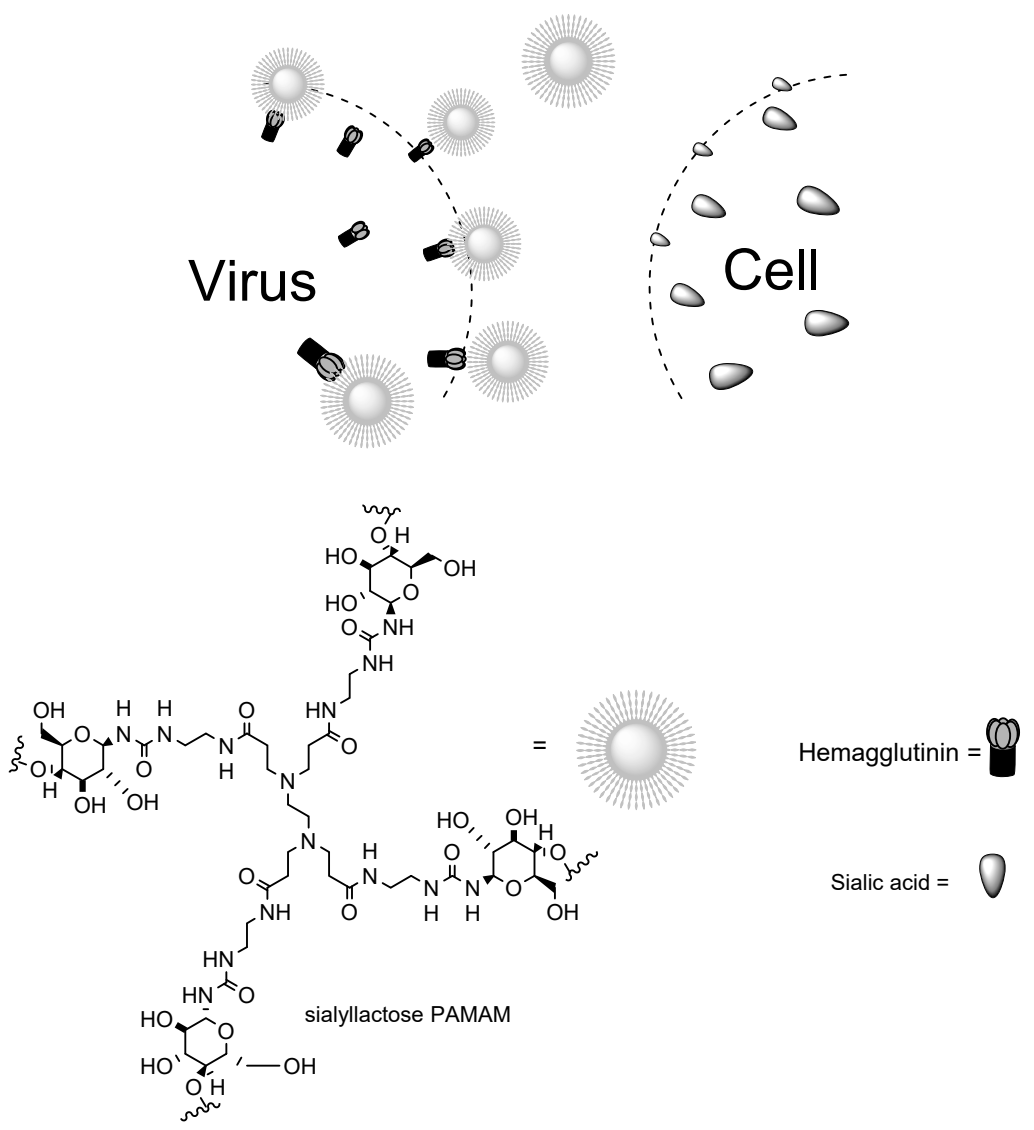

Figure 8. Cell-PAMAM competition for the hemagglutinin site of the virus.
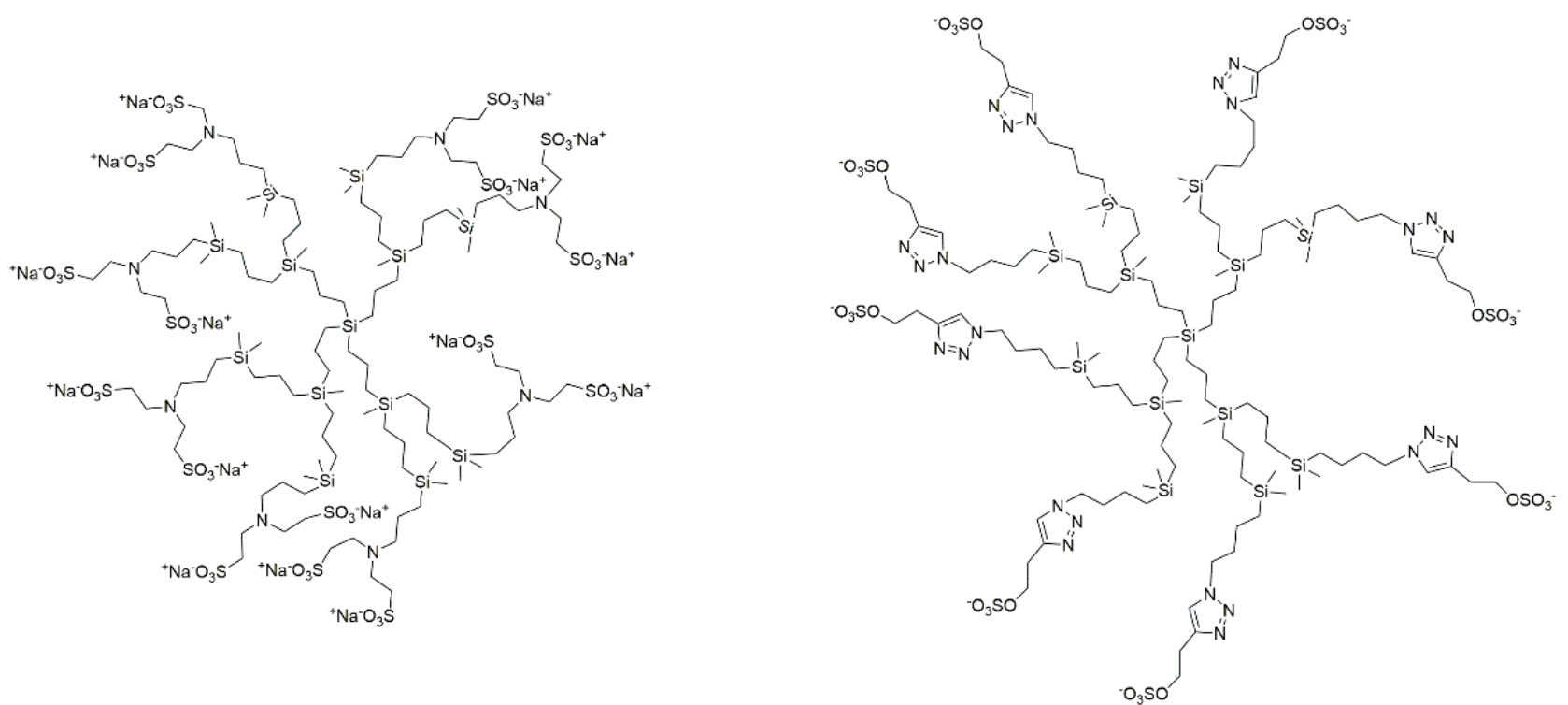

Figure 9. G2 (left) and G3 (right) poly-anionic carbosilane dendrimers. 


\section{Conclusions}

Dendrimers are useful candidates for a large number of applications, including the design of sustainable and low environmental impact advanced materials, catalytic processes, nano-delivery systems, and applications in the pharmacological field. Although they were studied for many years, the synthesis of these compounds still requires multi-step chemical reactions, which encompass two main categories: (a) the convergent approach; (b) the divergent approach [72]. These synthetic procedures can afford dendrimers with a controlled size and shape, finely tuning the properties of surface, branches, and core. In this context, solubility, reactivity, and biocompatibility can be modulated easier than polymers with a lower degree of structural order and repetitive motif [73]. The design of dendrimers is strictly related to their function requiring particular attention for medical applications [74]. Dendrimers have a well-defined nano-sized structure which makes them appropriate for oral, parenteral, pulmonary, and nasal drug delivery, due to their ability to cross the cell membrane by both transcellular and paracellular pathways. On the other hand, their toxicity is still a matter of debate $[75,76]$. Their main drawback relates to the fate of their interactions with biological membranes, which can in principle afford the disruption of the membrane and cell death [77]. In order to overcome these limitations and avoid undesirable side effects, several approaches emerged mainly based on the surface modifications strategy [73]. Although further studies are still required in order to fully characterize the safety profile of dendrimers, they possess unique delivery properties for both hydrophilic and lipophilic drugs, and some of them have received FDA approval, or, alternatively, are in the early stages of clinical trials [78].

Author Contributions: Conceptualization, B.M.B. and R.S.; writing-original draft preparation, B.M.B., A.F., L.B., C.Z. and S.C.; writing-review and editing, B.M.B. and R.S.; funding acquisition, R.S. All authors have read and agreed to the published version of the manuscript.

Funding: This work is supported by MIUR Ministero dell'Istruzione, dell'Università della Ricerca Italiano, project PRIN 2017, ORIGINALE CHEMIAE in Antiviral Strategy-Origin, and Modernization of Multi-Component Chemistry as a Source of Innovative Broad Spectrum Antiviral Strategy, cod. 2017BMK8JR.

Institutional Review Board Statement: Not applicable.

Informed Consent Statement: Not applicable.

Conflicts of Interest: The authors declare no conflict of interest.

\section{References}

1. Padilla De Jesús, O.L.; Ihre, H.R.; Gagne, L.; Fréchet, J.M.J.; Szoka, F.C. Polyester Dendritic Systems for Drug Delivery Applications: In Vitro and In Vivo Evaluation. Bioconjug. Chem. 2002, 13, 453-461. [CrossRef]

2. Zimmerman, S.C. Dendrimers in molecular recognition and self-assembly. Curr. Opin. Colloid Interface Sci. 1997, 2, 89-99. [CrossRef]

3. Zeng, F.; Zimmerman, S.C. Dendrimers in Supramolecular Chemistry: From Molecular Recognition to Self-Assembly. Chem. Rev. 1997, 97, 1681-1712. [CrossRef]

4. Hughes, G.A. Nanostructure-mediated drug delivery. Nanomed. Nanotechnol. Biol. Med. 2005, 1, 22-30. [CrossRef]

5. Kummu, M.; Ward, P.J.; de Moel, H.; Varis, O. Is physical water scarcity a new phenomenon? Global assessment of water shortage over the last two millennia. Environ. Res. Lett. 2010, 5, 34006. [CrossRef]

6. Maiti, S.; Mahajan, G.; Phadke, S.; Adivarekar, R. V Application of polyamidoamine dendrimer in reactive dyeing of cotton. J. Text. Inst. 2018, 109, 823-831. [CrossRef]

7. Li, J.; Wu, F.; Lin, L.; Guo, Y.; Liu, H.; Zhang, X. Flow fabrication of a highly efficient Pd/UiO-66- $\mathrm{NH}_{2}$ film capillary microreactor for 4-nitrophenol reduction. Chem. Eng. J. 2018, 333, 146-152. [CrossRef]

8. Nabil, B.; Morshed, M.N.; Ahmida, E.A.; Nemeshwaree, B.; Christine, C.; Julien, V.; Olivier, T.; Abdelkrim, A. Development of new multifunctional filter based nonwovens for organics pollutants reduction and detoxification: High catalytic and antibacterial activities. Chem. Eng. J. 2019, 356, 702-716. [CrossRef]

9. Chen, S.; Thota, S.; Wang, X.; Zhao, J. From solid to core shell to hollow Pt-Ag nanocrystals: Thermally controlled surface segregation to enhance catalytic activity and durability. J. Mater. Chem. A 2016, 4, 9038-9043. [CrossRef]

10. Self-assembly, R.E.; Res, C.; Jiang, D.; Aida, T. Photoisomerization in dendrimers by harvesting of low-energy photons. Nature 1997, 388, 5-7. 
11. Laipniece, L.; Kampars, V. Synthesis and Thermal Properties of Azobenzene Core Polyester Dendrimers with Trityl Groups at the Periphery. Key Eng. Mater. 2018, 762, 171-175. [CrossRef]

12. Xu, X.; Zhang, P.; Wu, B.; Xing, Y.; Shi, K.; Fang, W.; Yu, H.; Wang, G. Photochromic Dendrimers for Photoswitched Solid-To-Liquid Transitions and Solar Thermal Fuels. ACS Appl. Mater. Interfaces 2020, 12, 50135-50142. [CrossRef]

13. Han, G.D.; Park, S.S.; Liu, Y.; Zhitomirsky, D.; Cho, E.; Dincă, M.; Grossman, J.C. Photon energy storage materials with high energy densities based on diacetylene-azobenzene derivatives. J. Mater. Chem. A 2016, 4, 16157-16165. [CrossRef]

14. Weis, P.; Wang, D.; Wu, S. Visible-Light-Responsive Azopolymers with Inhibited $\pi-\pi$ Stacking Enable Fully Reversible Photopatterning. Macromolecules 2016, 49, 6368-6373. [CrossRef]

15. Zhou, H.; Xue, C.; Weis, P.; Suzuki, Y.; Huang, S.; Koynov, K. Photoswitching of glass transition temperatures of azobenzenecontaining polymers induces reversible solid-to-liquid transitions. Nat. Chem. 2017, 9, 145-151. [CrossRef] [PubMed]

16. Nemanashi, M. Dendrimers as alternative templates and pore-directing agents for the synthesis of micro- and mesoporous materials. J. Mater. Sci. 2018, 53, 12663-12678. [CrossRef]

17. Dai, H.; Yang, J.; Ma, J.; Chen, F.; Fei, Z.; Zhong, M. A green process for the synthesis of controllable mesoporous silica materials. Microporous Mesoporous Mater. 2012, 147, 281-285. [CrossRef]

18. Wolinsky, J.B.; Grinstaff, M.W. Therapeutic and diagnostic applications of dendrimers for cancer treatment. Adv. Drug Deliv. Rev. 2008, 60, 1037-1055. [CrossRef] [PubMed]

19. Singh, J.; Jain, K.; Mehra, N.K.; Jain, N.K. Dendrimers in anticancer drug delivery: Mechanism of interaction of drug and dendrimers. Artif. Cells Nanomed. Biotechnol. 2016, 44, 1626-1634. [CrossRef] [PubMed]

20. Alfei, S.; Marengo, B.; Zuccari, G.; Turrini, F.; Domenicotti, C. Dendrimer nanodevices and gallic acid as novel strategies to fight chemoresistance in neuroblastoma cells. Nanomaterials 2020, 10, 1243. [CrossRef]

21. Liu, Z.; Ren, Z.; Zhang, J.; Chuang, C. Role of ROS and Nutritional Antioxidants in Human Diseases. Front. Physiol. 2018, 9, 1-14. [CrossRef]

22. Angelo, S.D.; Martino, E.; Ilisso, C.P.; Bagarolo, M.L.; Porcelli, M.; Cacciapuoti, G. Pro-oxidant and pro-apoptotic activity of polyphenol extract from Annurca apple and its underlying mechanisms in human breast cancer cells. Int. J. Oncol. 2017, 51, 939-948. [CrossRef] [PubMed]

23. Lu, L.-L.; Lu, X.-Y. Solubilities of Gallic Acid and Its Esters in Water. J. Chem. Eng. Data 2007, 52, 37-39. [CrossRef]

24. Alfei, S.; Catena, S.; Turrini, F. Biodegradable and biocompatible spherical dendrimer nanoparticles with a gallic acid shell and a double-acting strong antioxidant activity as potential device to fight diseases from oxidative stress. Drug Deliv. Transl. Res. 2019, 10, 259-270. [CrossRef]

25. Lage, A.C.P.; Orlando Ladeira, L.; Mosqueira, L.; Magalhães Paniago, R.; Oliveira Castilho, R.; Amorim, J.M.; Pessoa, E.S.; Nuncira, J.; Faraco, A.A.G. Synthesis and characterization of gold nanorods using the natural products resveratrol, gallic acid, and a purified fraction of Stryphnodendron obovatum by seedless method. Environ. Nanotechnol. Monit. Manag. 2021, $16,100473$. [CrossRef]

26. Meschini, R.; D’Eliseo, D.; Filippi, S.; Bertini, L.; Bizzarri, B.M.; Botta, L.; Saladino, R.; Velotti, F. Tyrosinase-Treated Hydroxytyrosol-Enriched Olive Vegetation Waste with Increased Antioxidant Activity Promotes Autophagy and Inhibits the Inflammatory Response in Human THP-1 Monocytes. J. Agric. Food Chem. 2018, 66, 12274-12284. [CrossRef] [PubMed]

27. Botta, G.; Bizzarri, B.M.; Garozzo, A.; Timpanaro, R.; Bisignano, B.; Amatore, D.; Palamara, A.T.; Nencioni, L.; Saladino, R. Carbon nanotubes supported tyrosinase in the synthesis of lipophilic hydroxytyrosol and dihydrocaffeoyl catechols with antiviral activity against DNA and RNA viruses. Bioorg. Med. Chem. 2015, 23, 5345-5351. [CrossRef]

28. Mishra, M.K.; Kotta, K.; Hali, M.; Wykes, S.; Gerard, H.C.; Hudson, A.P.; Whittum-Hudson, J.A.; Kannan, R.M. PAMAM dendrimer-azithromycin conjugate nanodevices for the treatment of Chlamydia trachomatis infections. Nanomed. Nanotechnol. Biol. Med. 2011, 7, 935-944. [CrossRef]

29. Randomized, A.; Trial, C.; Schillinger, J.A.; Kissinger, P.; Calvet, H.; Whittington, W.L.H.; Ransom, R.A.Y.L.; Sternberg, M.R.; Berman, S.M.; Kent, C.K.; et al. Patient-Delivered Partner Treatment With Azithromycin to Prevent Repeated Chlamydia trachomatis Infection Among Women. Sex Transm Dis. 2003, 30, 49-56.

30. Martin, D.H.; Mroczkowski, T.F.; Dalu, Z.A.; McCarty, J.; Jones, R.B.; Hopkins, S.J.; Johnson, R.B. A Controlled Trial of a Single Dose of Azithromycin for the Treatment of Chlamydial Urethritis and Cervicitis. N. Engl. J. Med. 1992, 327, 921-925. [CrossRef]

31. Teow, H.M.; Zhou, Z.; Najlah, M.; Yusof, S.R.; Abbott, N.J.; D’Emanuele, A. Delivery of paclitaxel across cellular barriers using a dendrimer-based nanocarrier. Int. J. Pharm. 2013, 441, 701-711. [CrossRef] [PubMed]

32. Rowinsky, E.K.; Cazenave, L.A.; Donehower, R.C. Taxol: A Novel Investigation^Antimicrotubule Agent. J. Natl. Cancer Inst. 1990, 82, 1247-1259. [CrossRef] [PubMed]

33. Fellner, S.; Buschauer, A.; Fricker, G.; Fellner, S.; Bauer, B.; Miller, D.S.; Schaffrik, M.; Fankhänel, M.; Spruß, T.; Bernhardt, G.; et al. Transport of paclitaxel (Taxol) across the blood-brain barrier in vitro and in vivo Find the latest version: Transport of paclitaxel (Taxol) across the blood-brain barrier in vitro and in vivo. J. Clin. Investig. 2002, 110, 1309-1318. [CrossRef]

34. Najlah, M.; Freeman, S.; Attwood, D.; D’Emanuele, A. Synthesis and Assessment of First-Generation Polyamidoamine Dendrimer Prodrugs to Enhance the Cellular Permeability of P-gp Substrates. Bioconjug. Chem. 2007, 18, 937-946. [CrossRef] [PubMed]

35. Majoros, I.J.; Thomas, T.P.; Mehta, C.B.; Baker, J.R. Poly(amidoamine) Dendrimer-Based Multifunctional Engineered Nanodevice for Cancer Therapy. J. Med. Chem. 2005, 48, 5892-5899. [CrossRef] [PubMed] 
36. Narmani, A.; Mohammadnejad, J.; Yavari, K. Synthesis and evaluation of polyethylene glycol- and folic acid-conjugated polyamidoamine G4 dendrimer as nanocarrier. J. Drug Deliv. Sci. Technol. 2019, 50, 278-286. [CrossRef]

37. Menjoge, A.R.; Kannan, R.M.; Tomalia, D.A. Dendrimer-based drug and imaging conjugates: Design considerations for nanomedical applications. Drug Discov. Today 2010, 15, 171-185. [CrossRef]

38. Kesharwani, P.; Jain, K.; Jain, N.K. Dendrimer as nanocarrier for drug delivery. Prog. Polym. Sci. 2014, 39, 268-307. [CrossRef]

39. Chen, S.; Yang, K.; Tuguntaev, R.G.; Mozhi, A.; Zhang, J.; Wang, P.C.; Liang, X.-J. Targeting tumor microenvironment with PEG-based amphiphilic nanoparticles to overcome chemoresistance. Nanomed. Nanotechnol. Biol. Med. 2016, 12, 269-286. [CrossRef]

40. Liu, X.; He, B.; Xu, Z.; Yin, M.; Yang, W.; Zhang, H.; Cao, J.; Shen, J. A functionalized fluorescent dendrimer as a pesticide nanocarrier: Application in pest control. Nanoscale 2015, 7, 445-449. [CrossRef]

41. Maienfisch, P.; Angst, M.; Brandl, F.; Fischer, W.; Hofer, D.; Kayser, H.; Kobel, W.; Rindlisbacher, A.; Senn, R.; Steinemann, A. Chemistry and biology of thiamethoxam: A second generation neonicotinoid. Pest Manag. Sci. 2001, 57, 906-913. [CrossRef]

42. Liang, Q.; Xing, P.; Huang, Z.; Dong, J.; Sharpless, K.B.; Li, X.; Jiang, B. Palladium-Catalyzed, Ligand-Free Suzuki Reaction in Water Using Aryl Fluorosulfates. Org. Lett. 2015, 17, 1942-1945. [CrossRef]

43. Lipshutz, B.H.; Chung, D.W.; Rich, B. Sonogashira Couplings of Aryl Bromides: Room Temperature, Water Only, No Copper. Org. Lett. 2008, 10, 3793-3796. [CrossRef]

44. Tukhani, M.; Panahi, F.; Khalafi-Nezhad, A. Supported Palladium on Magnetic Nanoparticles-Starch Substrate (Pd-MNPSS): Highly Efficient Magnetic Reusable Catalyst for C-C Coupling Reactions in Water. ACS Sustain. Chem. Eng. 2018, 6, 1456-1467. [CrossRef]

45. Shaikh, T.M.; Hong, F. Palladium (II)—catalyzed Heck reaction of aryl halides and arylboronic acids with olefins under mild conditions. Belstein J. Org. Chem. 2013, 9, 1578-1588. [CrossRef]

46. Papp, A.; Galbács, G.; Molnár, Á. Recyclable ligand-free mesoporous heterogeneous Pd catalysts for Heck coupling. Tetrahedron Lett. 2005, 46, 7725-7728. [CrossRef]

47. Han, W.; Liu, N.; Liu, C.; Jin, Z.L. A ligand-free Heck reaction catalyzed by the in situ-generated palladium nanoparticles in PEG-400. Chin. Chem. Lett. 2010, 21, 1411-1414. [CrossRef]

48. Niknam, E.; Moaddeli, A.; Khalafi-Nezhad, A. Palladium anchored on guanidine-terminated magnetic dendrimer (G3-Gu-Pd): An efficient nano-sized catalyst for phosphorous-free Mizoroki-Heck and copper-free Sonogashira couplings in water. J. Organomet. Chem. 2020, 923, 121369. [CrossRef]

49. Alper, H.; Arya, P.; Bourque, S.C.; Jefferson, G.R.; Manzer, L.E. Heck reaction using palladium complexed to dendrimers on silica. Can. J. Chem. 2000, 78, 920-924. [CrossRef]

50. Bizzarri, B.M.; Fanelli, A.; Piccinino, D.; De Angelis, M.; Dolfa, C.; Palamara, A.T.; Nencioni, L.; Zippilli, C.; Crucianelli, M.; Saladino, R. Synthesis of Stilbene and Chalcone Inhibitors of Influenza A Virus by SBA-15 Supported Hoveyda-Grubbs Metathesis. Catalysts 2019, 9, 983. [CrossRef]

51. Karakhanov, E.; Maximov, A.; Kardasheva, Y.; Semernina, V.; Zolotukhina, A.; Ivanov, A.; Abbott, G.; Rosenberg, E.; Vinokurov, V. Pd Nanoparticles in Dendrimers Immobilized on Silica-Polyamine Composites as Catalysts for Selective Hydrogenation. ACS Appl. Mater. Interfaces 2014, 6, 8807-8816. [CrossRef]

52. Hughes, M.A.; Nielsen, D.; Rosenberg, E.; Gobetto, R.; Viale, A.; Burton, S.D.; Ferel, J. Structural Investigations of Silica Polyamine Composites: Surface Coverage, Metal Ion Coordination, and Ligand Modification. Ind. Eng. Chem. Res. 2006, 45, 6538-6547. [CrossRef]

53. Hughes, M.A.; Rosenberg, E. Characterization and Applications of Poly-Acetate Modified Silica Polyamine Composites. Sep. Sci. Technol. 2007, 42, 261-283. [CrossRef]

54. Landarani-isfahani, A.; Mohammadpoor-baltork, I.; Mirkhani, V. Palladium nanoparticles immobilized on a nano- silica triazine dendritic polymer: A recyclable and sustainable nanoreactor for C-S cross-coupling. RSC Adv. 2020, 10, 21198-21205. [CrossRef]

55. Lakshmi, K.; Rangasamy, R. Synthetic modification of silica coated magnetite cored PAMAM dendrimer to enrich branched Amine groups and peripheral carboxyl groups for environmental remediation. J. Mol. Struct. 2021, 1224, 129081. [CrossRef]

56. Caminade, A.; Ouali, A.; Majoral, J.; Caminade, A. Chem Soc Rev Organocatalysis with dendrimers. Chem. Soc. Rev. 2012, 41, 4113-4125. [CrossRef]

57. Avudaiappan, G.; Unnikrishnan, V.; Sreekumar, K. Convenient Synthesis of Dihydropyridine and Dihydropyrimidinethione Derivatives Using a Porphyrin Cored G1 PAMAM Dendrimer as a Homogeneous Catalyst. Chem. Sel. 2020, 5, 506-514. [CrossRef]

58. Sherlymole, P.B.; Anuf, R.; Krishna, A. Dendrimer with Interior Cavity as Catalytic Pockets for Substrate Molecules: Synthesis of Bisimidazoles and Molecular Docking Study. ChemistrySelect 2020, 5, 5055-5065. [CrossRef]

59. Hiba, K.; Sreekumar, K. Multi- arm dendronized polymer as a unimolecular micelle: Synthesis, characterization and application as organocatalyst in the synthesis of N-unsubstituted 1,2,3-triazoles. React. Funct. Polym. 2021, 160, 104827. [CrossRef]

60. Pourjavadi, A.; Hosseini, S.H. Functionalized Poly(Amidoamine) Dendrimer as a Strong Ionic Brønsted Acid Organocatalyst for Protection/Deprotection of Aldehydes. Phosphorus. Sulfur Silicon Relat. Elem. 2014, 189, 1794-1801. [CrossRef]

61. Bizzarri, B.M.; Fanelli, A.; Botta, L.; Sadun, C.; Gontrani, L.; Ferella, F.; Crucianelli, M.; Saladino, R. Dendrimer crown-ether tethered multi-wall carbon nanotubes support methyltrioxorhenium in the selective oxidation of olefins to epoxides. RSC Adv. 2020, 10, 17185-17194. [CrossRef] 
62. Bizzarri, B.M.; Rotelli, L.; Botta, G.; Saladino, R. Current Advances in L-DOPA and DOPA-Peptidomimetics: Chemistry, Applications and Biological Activity. Curr. Med. Chem. 2015, 22, 4138-4165. [CrossRef] [PubMed]

63. Bizzarri, B.M.; Pieri, C.; Botta, G.; Arabuli, L.; Mosesso, P.; Cinelli, S.; Schinoppi, A.; Saladino, R. Synthesis and antioxidant activity of DOPA peptidomimetics by a novel IBX mediated aromatic oxidative functionalization. RSC Adv. 2015, 5, 60354-60364. [CrossRef]

64. Esfand, R.; Tomalia, D.A. Poly(amidoamine) (PAMAM) dendrimers: From biomimicry to drug delivery and biomedical applications. Drug Discov. Today 2001, 6, 427-436. [CrossRef]

65. Oka, H.; Onaga, T.; Koyama, T.; Guo, C.-T.; Suzuki, Y.; Esumi, Y.; Hatano, K.; Terunuma, D.; Matsuoka, K. Sialyl $\alpha(2 \rightarrow 3)$ lactose clusters using carbosilane dendrimer core scaffolds as influenza hemagglutinin blockers. Bioorg. Med. Chem. Lett. 2008, 18, 4405-4408. [CrossRef]

66. Rodríguez-Izquierdo, I.; Natalia, C.; García, F.; Muñoz-Fernandez, M.D.L. Ángeles G2-S16 sulfonate dendrimer as new therapy for treatment failure in HIV-1 entry inhibitors. Nanomedicine 2019, 14, 1095-1107. [CrossRef]

67. Bourne, N.; Stanberry, L.R.; Kern, E.R.; Holan, G.; Matthews, B.; Bernstein, D.I. Dendrimers, a New Class of Candidate Topical Microbicides with Activity against Herpes Simplex Virus Infection. Antimicrob. Agents Chemother. 2000, 44, 2471-2474. [CrossRef]

68. Razinkov, V.; Gazumyan, A.; Nikitenko, A.; Ellestad, G.; Krishnamurthy, G. RFI-641 inhibits entry of respiratory syncytial virus via interactions with fusion protein. Chem. Biol. 2001, 8, 645-659. [CrossRef]

69. Günther, S.C.; Maier, J.D.; Vetter, J.; Podvalnyy, N.; Khanzhin, N.; Hennet, T.; Stertz, S. Antiviral potential of 3'-sialyllactose- and 6 '-sialyllactose-conjugated dendritic polymers against human and avian influenza viruses. Sci. Rep. 2020, 10, 1-9. [CrossRef] [PubMed]

70. Kandeel, M.; Al-Taher, A.; Park, B.K.; Kwon, H.J.; Al-Nazawi, M. A pilot study of the antiviral activity of anionic and cationic polyamidoamine dendrimers against the Middle East respiratory syndrome coronavirus. J. Med. Virol. 2020, 92, 1665-1670. [CrossRef] [PubMed]

71. Rodríguez, R.; Rodríguez, I.R.; Sánchez, R.J.; Pavicic, C.; Muñoz, E.; Ángeles, M.; Fernández, M. Polyanionic carbosilane dendrimers as a new adjuvant in combination with latency reversal agents for HIV treatment. J. Nanobiotechnol. 2019, 17, 1-8. [CrossRef] [PubMed]

72. Malkoch, M.; García-Gallego, S. CHAPTER 1: Introduction to Dendrimers and Other Dendritic Polymers. In Dendrimer Chemistry: Synthetic Approaches Towards Complex Architectures; Royal Society of Chemistry: London, UK, 2020; pp. 1-20. [CrossRef]

73. Santos, A.; Veiga, F.; Figueiras, A. Dendrimers as Pharmaceutical Excipients: Synthesis, Properties, Toxicity and Biomedical Applications. Materials 2019, 13, 65. [CrossRef] [PubMed]

74. Kojima, C.; Saito, K.; Kondo, E. Design of peptide-dendrimer conjugates with tumor homing and antitumor effects. Res. Chem. Intermed. 2018, 44, 4685-4695. [CrossRef]

75. Li, C.; Huang, J.; Ding, P.; Wang, M.; Guo, X.; Stuart, M.A.C.; Wang, J. Hierarchical polyion complex vesicles from PAMAM dendrimers. J. Colloid Interface Sci. 2021, 606, 307-316. [CrossRef] [PubMed]

76. Devadas, B.; Periasamy, A.P.; Bouzek, K. A review on poly(amidoamine) dendrimer encapsulated nanoparticles synthesis and usage in energy conversion and storage applications. Coord. Chem. Rev. 2021, 444, 214062. [CrossRef]

77. Chis, A.A.; Dobrea, C.; Morgovan, C.; Arseniu, A.M.; Liviu Rus, L.; Butuca, A.; Juncan, A.M.; Totan, M.; Vonica-Tincu, A.L.; Cormos, G.; et al. Applications and Limitations of Dendrimers in Biomedicine. Molecules 2020, 25, 3982. [CrossRef] [PubMed]

78. Chauhan, A.; Kulhari, H. Pharmaceutical Applications of Dendrimers, 1st ed.; Elsevier: Amsterdam, The Netherlands, 2020; pp. 251-269. [CrossRef] 